\title{
An integrated 1D-2D hydraulic modelling approach to assess the sensitivity of a coastal region to compound flooding hazard under climate change
}

\author{
Ulysse Pasquier $^{1}$ (D) $\cdot \mathrm{Yi} \mathrm{He}^{1} \cdot$ Simon Hooton $^{2} \cdot$ Marisa Goulden $^{3} \cdot$ \\ Kevin M. Hiscock ${ }^{4}$
}

Received: 26 December 2017 / Accepted: 21 August 2018/Published online: 30 August 2018 (C) The Author(s) 2018

\begin{abstract}
Coastal regions are dynamic areas that often lie at the junction of different natural hazards. Extreme events such as storm surges and high precipitation are significant sources of concern for flood management. As climatic changes and sea-level rise put further pressure on these vulnerable systems, there is a need for a better understanding of the implications of compounding hazards. Recent computational advances in hydraulic modelling offer new opportunities to support decision-making and adaptation. Our research makes use of recently released features in the HEC-RAS version 5.0 software to develop an integrated 1D-2D hydrodynamic model. Using extreme value analysis with the Peaks-OverThreshold method to define extreme scenarios, the model was applied to the eastern coast of the UK. The sensitivity of the protected wetland known as the Broads to a combination of fluvial, tidal and coastal sources of flooding was assessed, accounting for different rates of twenty-first century sea-level rise up to the year 2100. The 1D-2D approach led to a more detailed representation of inundation in coastal urban areas, while allowing for interactions with more fluvially dominated inland areas to be captured. While flooding was primarily driven by increased sea levels, combined events exacerbated flooded area by $5-40 \%$ and average depth by $10-32 \%$, affecting different locations depending on the scenario. The results emphasise the importance of catchment-scale strategies that account for potentially interacting sources of flooding.
\end{abstract}

Keywords Flooding · Hydraulic modelling · Storm surge - Sea-level rise · Compound hazard · Extreme value analysis

\section{Introduction}

\subsection{Flooding hazard in a changing climate}

Floods are significant and regular threats to a great number of people worldwide. In Europe, flooding represents the most costly natural hazard (Whitfield 2012) with damages on the rise as population grows in flood-prone areas (Barredo 2009) and human activities

Extended author information available on the last page of the article 
lead to land-cover changes (He et al. 2013). Recent severe disruptions in the UK during the $2013 / 2014$ and 2015/2016 winters were reminders of the devastating potential of such extreme floods. While there is still much uncertainty in attributing a climate signal to a possible trend in extreme events (Wilby et al. 2008), climate models suggest that climate change could lead to more frequent and intense precipitation in certain regions (Wang et al. 2017), thereby increasing flood hazard. On the other hand-as the Intergovernmental Panel on Climate Change (IPCC) reported (Church et al. 2013) — there is a high level of confidence that sea levels will continue to rise throughout and beyond the next century. Moreover, changes in mean sea level (MSL) are fundamental drivers for extreme sea levels (Menéndez and Woodworth 2010), thereby putting further pressure on coastal regions. While the development of flood defences and forecasting has prevented a significant increase in coastal flooding (Stevens et al. 2016), these trends highlight the need for better preparedness and an improved understanding of future hazards.

Coastal environments are vulnerable systems that can act as the interface for different hazards. Groundwater, pluvial (surface water), fluvial (river), tidal and coastal sources of flooding can all exist in areas near the sea, which also often host dense population centres. As presented by Wong et al. (2014) there is ample research on the risks coastal regions face and therefore the importance of adaptive measures. More recently, increasing attention has been dedicated to compounding extreme events (e.g. Kew et al. 2013; van den Hurk et al. 2015). Coinciding hazards, such as storm surges and precipitation, can lead to impacts that would otherwise not have been observed had they occurred separately and can therefore have significant implications for flooding risk. A number of studies have looked to determine the dependence between these hydrological extremes (e.g. Zheng et al. 2014), including in the UK (Svensson and Jones 2002). While a significant dependence is not always found (Klerk et al. 2015), it remains highly uncertain how the climate will influence this relation in the future. Wahl et al. (2015) for example, observed in the USA a change towards storms surges that also promote high rainfall. The threat of combined events from different origins underlines the importance of adopting a holistic stance in assessing flood hazard.

\subsection{Integrated flood modelling}

There has been in recent decades a paradigm shift towards a broader catchment-scale approach for flood risk management in Europe, as demonstrated by the European Union's Water Framework Directive (2000) and Floods Directive (2007). Integrated strategies that identify synergies at the river basin level, notably between rural and urban areas, have gained increasing support (Rouillard et al. 2015). Isolated actions to mitigate flooding run the risk of leading to unwanted outcomes. For example, a flood alleviation measure taken at a location in a catchment can have downstream impacts that should be taken into account. An integrated approach is moreover justified when sources of flooding are varied, originate from different hydrological processes and interact with each other. The lack of adequate information on these interactions remains an important hurdle for decisionmaking.

There is a need for modelling methods to follow the above trends to be able to provide information required for planning. Hydrodynamic models solve equations of fluid motion to replicate the movement of water and are widely used to assess flooding risk. The simplest and most common practice is to use one-dimensional (1D) models that treat flow one-dimensionally along the river channel. This assumption is appropriate in many 
situations but may not be suitable for flood mapping in areas where flow is expected to spread, such as in wide floodplains (Néelz and Pender 2009). Alternatively, while twodimensional (2D) models can provide more detailed results and have gained in popularity, they remain computationally and data intensive and therefore difficult to apply to large areas. Recent advances and software developments offer new opportunities to help meet the goals of integrated approaches by allowing for linkages between 1D and 2D models (Teng et al. 2017). Coupled 1D-2D models can dynamically represent coastal, urban, river and floodplains interactions and are therefore well suited to assess the impact of flooding from different sources. While-as was shown in the previous section-there has been an increasing number of studies looking at the impact of combined events on flooding, 1D-2D hydraulic models remain relatively new tools in this field that are subject to more investigation (Webster et al. 2014).

This paper aims to present a modelling methodology to assess the sensitivity of a coastal area to the combination of fluvial, tidal and coastal sources of flooding. The fitness for use of an integrated 1D-2D hydraulic modelling approach is to be evaluated in the context of the Broads National Park in the UK. The aim of this study is to provide a modelling framework for simulating compound modelling scenarios. In this study, we are not providing a comprehensive probabilistic flood risk assessment framework. Finally, an aim of the modelling design is to understand the implications of portraying interacting sources of flooding from opposite ends of a river sub-catchment.

\section{Study area: the Broads, UK}

Located on the eastern coast of England, the Norfolk and Suffolk Broads is Britain's largest designated wetland. The network of rivers and shallow lakes—or "broads" — covers a total area of $303 \mathrm{~km}^{2}$ at the downstream end of the $3200 \mathrm{~km}^{2}$ Broadland Rivers Catchment (Fig. 1). The low-lying national park holds importance for natural conservation, navigation, recreation and tourism, as well as for its cultural features. Land use is mostly shared between coastal and floodplain grazing marshes, fens and arable land. The Broads are bounded by several urban centres, namely, Norwich, Lowestoft and Great Yarmouth, where the River Yare flows into the North Sea.

The Broads Authority was established in 1988 to coordinate the management of land and water in the Broads because of its special landscape. While offering many economic and environmental opportunities, water also presents considerable risks. The Broads have a long history of flooding driven by its low elevation and proximity to the sea. The 1953 storm had severe impacts in East Anglia, as it did throughout much of the North Sea coasts. The event led to significant investments in flood protection and forecasting. Most recently, the Broads Flood Alleviation Project has been responsible for the improvement and maintenance of the $240 \mathrm{~km}$ of flood defences that exist in the Broads. The scheme has been successful in limiting inundation, and defences coped well during the largest storm surge since 1953 in December 2013. As climatic conditions change and sea level rises, the Broads are however anticipated to face further pressures and there remains uncertainty over the best strategic line to follow to manage flood risk.

Flood management in the Broads is a challenging task due to the area's complex hydrology and range of potential flooding sources. In the context of the Broads, coastal flooding - or the ingress of water inland directly from the sea-is differentiated from tidal flooding, caused by the propagation of the tidal wave upriver. Although coastal flooding can have devastating consequences (Wu et al. 2015), tidal flooding is still the main concern 

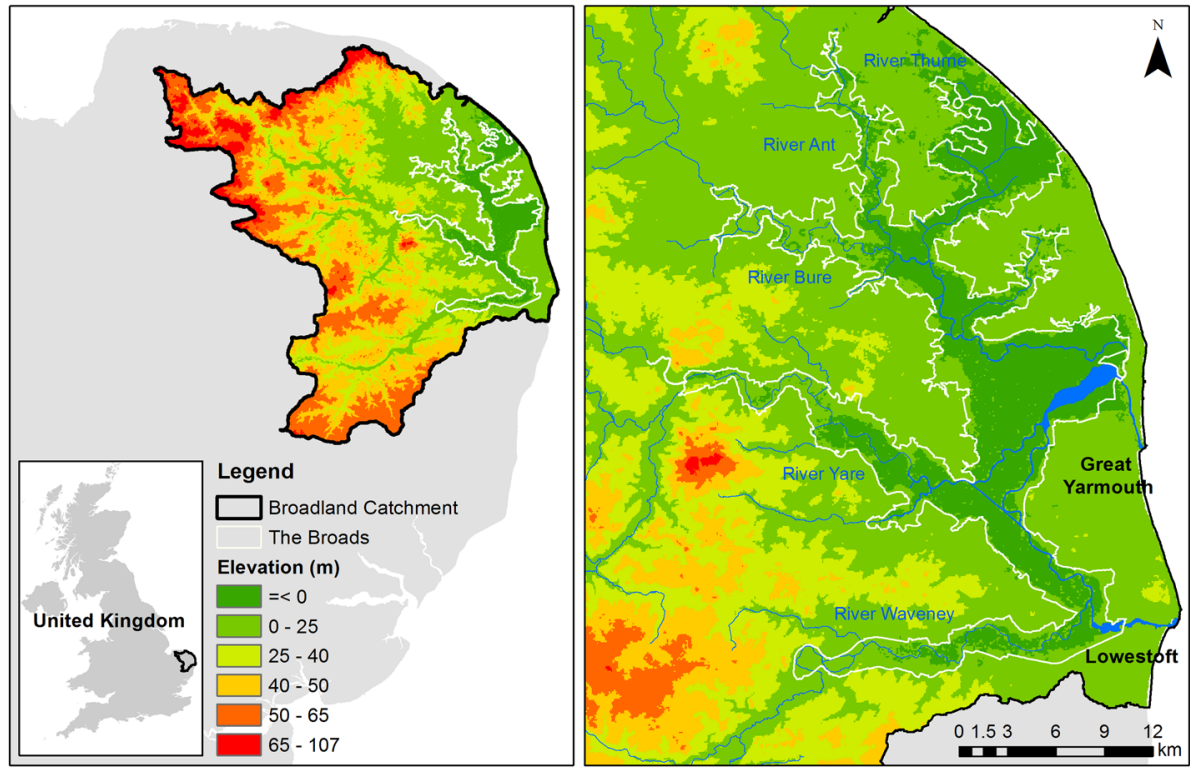

Fig. 1 The Broads National Park is part of the Broadland River Catchment in eastern England. The majority of the area within the Broads' administrative boundaries lies below sea level

in many parts of the Broads as low gradients along the key rivers allow the tidal influence to travel throughout much of the area. Major floods have also occurred due to heavy rainfall, for example in 1959 and 1968. Past studies in the catchment have found that fluvial floods and surge events occurred independently (Mantz and Wakeling 1979). There remains however a risk of combined river and tidal flooding in the Broads. Extreme sea levels can indeed coincide with high river flows or prevent proper drainage to cause flooding, for example on the River Bure (Environment Agency 2009). While they can exacerbate the impact of inundation, little research has focused on combined events and how they could affect the Broads in the future with projections of climate change and sealevel rise (SLR).

\section{Data and methods}

\subsection{Environmental conditions}

\subsubsection{Sea level}

Tide gauge data of sea level between 1964 and 2015 were obtained from the British Oceanographic Data Centre. The observations were made in Lowestoft $\left(52^{\circ} 28^{\prime} 23.0556^{\prime \prime} \mathrm{N}\right.$, $\left.1^{\circ} 45^{\prime} 0.81^{\prime \prime} \mathrm{E}\right)$, approximately $10 \mathrm{~km}$ south of Great Yarmouth. The east coast of England experiences a semidiurnal tidal regime. Chart datum at Lowestoft is located $1.50 \mathrm{~m}$ below ordnance datum (OD, at Newlyn). Sea level was recorded every $60 \mathrm{~min}$ prior to 1992 and every 15 min after 1992, with fewer than $3 \%$ missing data in the whole dataset.

A critical driver for flood hazard in coastal areas is peak sea level during extreme events that may occur, for instance, when a large storm surge coincides with high spring tide. The 
historical sea level data at Lowestoft were analysed with extreme value statistics to determine the probability of occurrence of extreme sea levels. Block maxima and Peaks Over Threshold (POT) are the primary approaches for extreme value analysis (EVA), and both have been used in the past to analyse sea levels (Webster et al. 2014; Haigh et al. 2016). POT however allows for more control over which events are included in the extreme value distribution and has been found to perform better than the more traditional Block Maxima method in previous flood frequency studies (Arns et al. 2013, Bezak et al. 2014). An average of 1.92 extreme values per year were thereby extracted that exceeded a level of $1.90 \mathrm{~m}$ above ordnance datum (maOD), corresponding to the 99.7 th percentile of high tide peak sea levels (Fig. 2).

Due to the thermal expansion of water, melting glaciers and vertical land movement, relative sea level has been rising at Lowestoft at a rate of $2.70 \pm 0.40 \mathrm{~mm} \mathrm{a}^{-1}$ in the second half of the twentieth century (Wahl et al. 2013). A simple additive method was used to detrend the data and remove yearly changes in MSL with 2015 serving as the reference year. Moreover, the chosen peaks were declustered using a 48-h window to ensure only independent events were retained. A Generalised Pareto (GP) distribution was fitted to the remaining sea levels to determine return periods relative to the year 2015. The GP distribution has the distribution function

$$
F(x)=1-\left(1-\frac{k x}{\alpha}\right)^{1 / k}
$$

where the distribution's parameters $\alpha$, the scale parameter, and $k$, the shape parameter, are determined with the maximum likelihood estimation method. The fit of the distribution was evaluated with plotting positions using the Gringorten formula, which is widely recognised for GP distributions (Chen and Sign 2017).

\subsubsection{River discharge}

Daily mean river flow data at Horstead Mill $\left(52^{\circ} 43^{\prime} 25.8672^{\prime \prime} \mathrm{N}, 1^{\circ} 21^{\prime} 14.8745^{\prime \prime} \mathrm{E}\right)$ on the River Bure between 1974 and 2015 were obtained from the National River Flow Archive. In the same way that sea levels were analysed, the POT method was used to determine the probability of extreme discharge. The GP distribution provided a better fit than a generalised extreme value distribution, which was tested using annual maxima of river flow. The mean residual life plot, an exploratory technique described by Saeed Far and Abd. Wahab (2016), here helped identify an appropriate threshold. An average of 2.20 extreme values

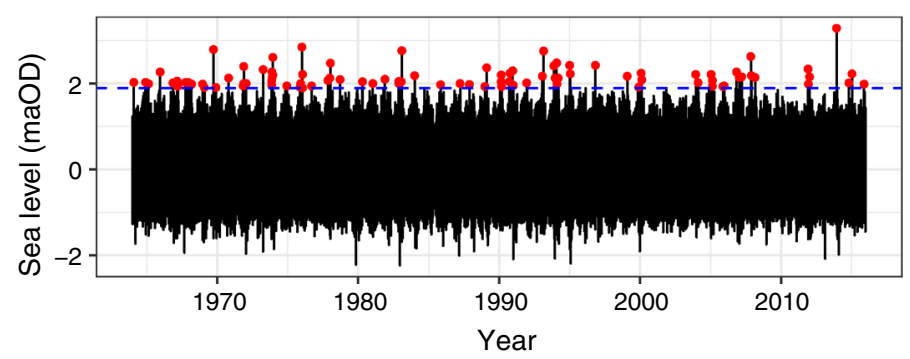

Fig. 2 Sea level relative to ordnance datum at Lowestoft, UK between 1964 and 2015. Red points represent sea level peaks above a defined threshold (blue, dashed horizontal line) chosen to fit a Generalised Pareto distribution and derive extreme return levels 
per year were extracted that exceeded a level of $6.83 \mathrm{~m}^{3} \mathrm{~s}^{-1}$, corresponding to the 99th percentile of river discharge levels (Fig. 3). An extreme value of $30.80 \mathrm{~m}^{3} \mathrm{~s}^{-1}$ in 1981 particularly stood out from other peaks corresponding to an event that saw approximately 70 mm of rainfall in Norfolk between 25 April 1981 and 27 April 1981.

\subsection{Hydrodynamic model: HEC-RAS}

\subsubsection{Model structure and domain}

A 1D-2D hydraulic model was developed with the HEC-RAS software to map flooding extent and depth under different extreme scenarios. HEC-RAS is a free modelling tool developed by the United States Army Corps of Engineers (USACE). Among its many applications, the software is well tested for flood mapping in both coastal (e.g. Ray et al. 2011) and fluvial (e.g. Javaheri and Babbar-Sebens 2014) environments as well as to assess the impacts of climate change (e.g. Shrestha and Lohpainsankrit 2016). Previously limited to 1D models, a new version of HEC-RAS (version 5.0) was released in 2016 allowing for full 2D modelling and linkages between 1D and 2D features. While other tools such as Flood Modeller, developed by $\mathrm{CH} 2 \mathrm{M}$, or MIKE FLOOD, developed by the Danish Hydraulic Institute (DHI), also offer the possibility to combine 1D and 2D models, HECRAS is the non-commercial software that has not previously been applied to the Broads. Moreover, although the new 2D capabilities of HEC-RAS offer opportunities for flood mapping, the model still requires testing for different applications (Vozinaki et al. 2017). The new HEC-RAS version was used, for example, by Quiroga et al. (2016) and Patel et al. (2017) to simulate past fluvial floods. Due to its recent release however, few studies are yet to apply HEC-RAS version 5 in coastal regions.

The Broads is a hydrologically complex and highly engineered area. The main rivers that make up the wetland-namely, the River Bure, River Yare and River Waveney-are narrow and constrained by high levees. These defences protect over 21,000 ha in the Broads and over 1700 properties. In many parts of the Broads, the flood banks are significantly higher than the wide floodplains they protect. Much of the Broads floodplain has a low elevation gradient and lies below sea level. A failure in the defences can therefore lead to widespread flooding. An accurate representation of the study area's elevation is a fundamental requirement in hydraulic modelling. A composited digital terrain model (DTM) derived from light detection and ranging (LIDAR) data was obtained from the Environment Agency. The DTM had a resolution of $2 \mathrm{~m}$ by $2 \mathrm{~m}$ with a vertical accuracy



Fig. 3 River discharge at Horstead Mill between 1974 and 2015. The points represent discharge peaks above a defined threshold (blue, dashed horizontal line) chosen to fit a Generalised Pareto distribution and derive extreme return levels 
of $\pm 5 \mathrm{~cm}$ and provided a good coverage of the study area. River bathymetry is also an important input to the hydraulic model. As LIDAR data are poor at representing underwater elevations, river surveys from the Broads Authority conducted between 2011 and 2015 were used to correct the DTM within river channels. Moreover, information from the Environment Agency on flood defences in the area ensured that the latest levee heights were included in the DTM.

The 1D-2D hydraulic model shown in Fig. 4 was built in HEC-GeoRAS, the ArcGIS extension for HEC-RAS. Cross sections of the river channels were drawn approximately every 30-50 m from one river bank to the other, forming the model's main 1D feature. A common method for out-of-bank flood modelling and mapping is to extend the model's cross sections into the floodplain. This technique is however not suitable for flood mapping in wide floodplains, which are common throughout the Broads. Instead, the floodplain is represented as a series of flood cells, called storage areas in HEC-RAS, where water can spill into from the rivers. The storage areas are separated by high ground and connected to the river cross sections in the HEC-RAS model with lateral structures, in this case, the

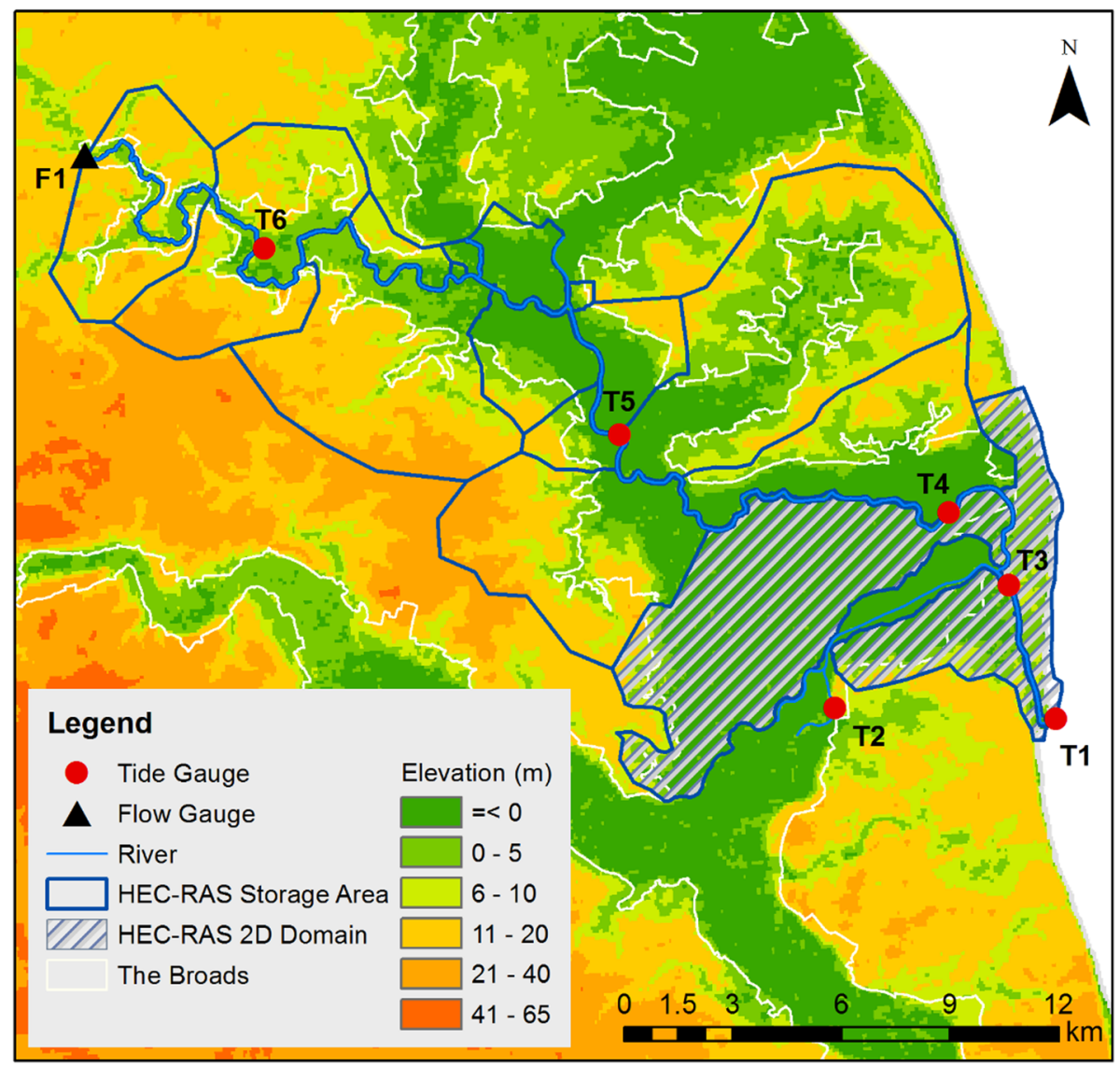

Fig. 4 HEC-RAS model domain. Storage areas and 2D areas are used to represent overbank flow in upstream and downstream portions of the model domain, respectively. Observations of river levels and discharge are available at different gauges: F1 (Horstead Mill), T1 (Great Yarmouth), T2 (Burgh Castle), T3 (Haven Bridge), T4 (Three Mile House), T5 (Acle Bridge) and T6 (Hoveton Broad) 
flood defences on both sides of the rivers. Water will flow into the storage areas if the river level surpasses the corresponding height of the flood defence. Storage areas are 1D features represented using a volume-elevation table calculated with the DTM data and can provide satisfactory accounts of floodplain flow with little computational demands. More detail is however required in urban areas and where flow is likely to spread significantly as is the case at the downstream end of the study area. 2D flexible meshes were therefore set up and dynamically linked to the river cross sections in Great Yarmouth and the large low-lying area called the Halvergate Marshes. The mesh size varied between $10 \mathrm{~m}$ and $50 \mathrm{~m}$ and aligned to capture high ground features such as flood defences, roads, and railway tracks. A $2 \mathrm{D}$ domain is appropriate at the coast as it has the added benefit of being capable of portraying flooding occurring directly from the sea-in case of the overtopping of defences (coastal flooding) — and how it may interact with other sources of flooding.

The hydraulic model covers a $260 \mathrm{~km}$ area from the mouth of the River Yare in Great Yarmouth to Horstead Mill, approximately $40 \mathrm{~km}$ upstream on the River Bure. Portions of the River Bure's tributaries-namely the River Ant and the River Thurne-are also included. The location of a flow gauge at Horstead Mill was chosen for the upstream boundary of the model. As a predominantly tidally influenced area, gauges in the Broads primarily measure river levels, and their locations are presented in Fig. 4. Land-cover data were obtained from the EDINA Environment Digimap Service as supplied by the Centre for Ecology and Hydrology (CEH) for the year 2015 (Fig. 5). The original classification was simplified to represent the main land uses across the HEC-RAS 2D areas. The large floodplains of the Broads consist first and foremost of grassland and grazing marshes. Land used for arable crops and horticulture tends to be located on the higher ground and make up most of the rest of the area. The most significant urban area is Great Yarmouth on both sides of the River Yare.

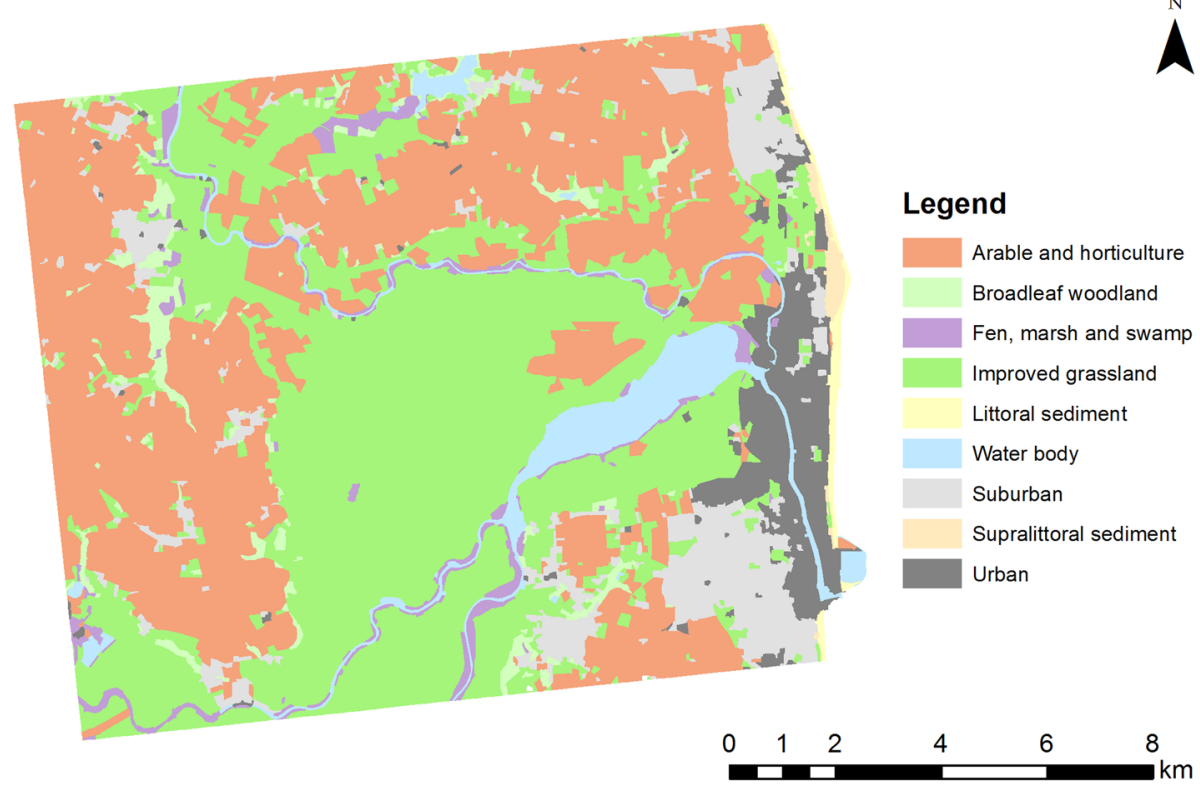

Fig. 5 Land-cover map of the downstream end of the Broads near Great Yarmouth in 2015 (Data obtained from EDINA Environment Digimap Services) 


\subsubsection{Unsteady flow analysis}

Flood events were simulated in HEC-RAS under unsteady flow conditions. The HEC-RAS model solves the full Saint-Venant equations for the conservation of mass and momentum:

$$
\begin{gathered}
\frac{\partial \zeta}{\partial t}+\frac{\partial u}{\partial x}+\frac{\partial v}{\partial y}=0 \\
\frac{\partial u}{\partial t}+\frac{\partial}{\partial x}\left(\frac{u^{2}}{h}\right)+\frac{\partial}{\partial y}\left(\frac{u v}{h}\right)=-\frac{n^{2} u g \sqrt{u^{2}+v^{2}}}{h^{2}}-g h \frac{\partial \zeta}{\partial x}+u f+\frac{\partial}{\rho \partial x}\left(h \tau_{x x}\right)+\frac{\partial}{\rho \partial y}\left(h \tau_{x y}\right) \\
\frac{\partial v}{\partial t}+\frac{\partial}{\partial x}\left(\frac{v^{2}}{h}\right)+\frac{\partial}{\partial y}\left(\frac{u v}{h}\right)=-\frac{n^{2} v g \sqrt{u^{2}+v^{2}}}{h^{2}}-g h \frac{\partial \zeta}{\partial y}+v f+\frac{\partial}{\rho \partial y}\left(h \tau_{y y}\right)+\frac{\partial}{\rho \partial x}\left(h \tau_{x y}\right)
\end{gathered}
$$

where $h$ is the water depth (m), $u$ and $v$ are the specific flow in the $x$ and $y$ directions $\left(\mathrm{m}^{2} \mathrm{~s}^{-1}\right), \zeta$ is the surface elevation $(\mathrm{m}), g$ is the gravitational acceleration $\left(\mathrm{m} \mathrm{s}^{-2}\right), n$ is the Manning's resistance, $\rho$ is the water density $\left(\mathrm{kg} \mathrm{m}^{-3}\right), f$ is the Coriolis parameter and $\tau_{x x}$, $\tau_{x y}$ and $\tau_{y y}$ are the components of the effective shear stress (Quiroga et al. 2016). While HEC-RAS offers the option of solving the diffusion-wave approximation of the equations in two dimensions, this method cannot be used for the propagation of waves in tidally influenced conditions. The full momentum equations were therefore chosen. A computational time step of $10 \mathrm{~s}$ was selected based on the guidelines proposed by the CourantFriedrichs-Lewy condition:

$$
C=\frac{\mathrm{V} \Delta T}{\Delta x} \leq 1 \quad \text { Or } \quad \Delta T \leq \frac{\Delta x}{V}(\text { with } C=1.0)
$$

where $C$ is the Courant Number, $V$ is the flood wave velocity $\left(\mathrm{m} \mathrm{s}^{-1}\right), \Delta T$ is the computational time step (s) and $\Delta x$ is the average cell size (m). The performance of the model was tested with the Nash-Sutcliffe Efficiency (NSE) coefficient defined as:

$$
1-\frac{\sum_{t=1}^{n}\left(Q_{m}^{t}-Q_{o}^{t}\right)^{2}}{\sum_{t=1}^{n}\left(Q_{o}^{t}-\overline{Q_{o}}\right)^{2}}
$$

where $Q_{o}^{t}$ are observations at time $t$ and $Q_{m}^{t}$ are modelled values.

The HEC-RAS model boundary conditions consisted of a stage hydrograph downstream and a flow hydrograph upstream. The observed sea level can be considered as the sum of MSL, an astronomical tide component and a non-tidal residual (Pugh 1996). The tidal component is the response of sea level to astronomical forces such as the relative position of the moon and the sun, and can be isolated with a harmonic analysis of sea levels. What remains when the MSL is also removed is termed the non-tidal residual and primarily represents the meteorological impact on sea level from a surge.

An average storm surge shape was determined by identifying the 20 highest storm surges since 1964 at Lowestoft (Fig. 6a). Ideally, local storm surge models can be used to reconstruct more physically realistic conditions in the definition of synthetic events (e.g. Villatoro et al. 2014). The chosen method of generalisation was however described by the Environment Agency (McMillan et al. 2011) as providing a reasonable means to derive a design surge profile. Although the averaging leads to a smoothed profile, the resulting 

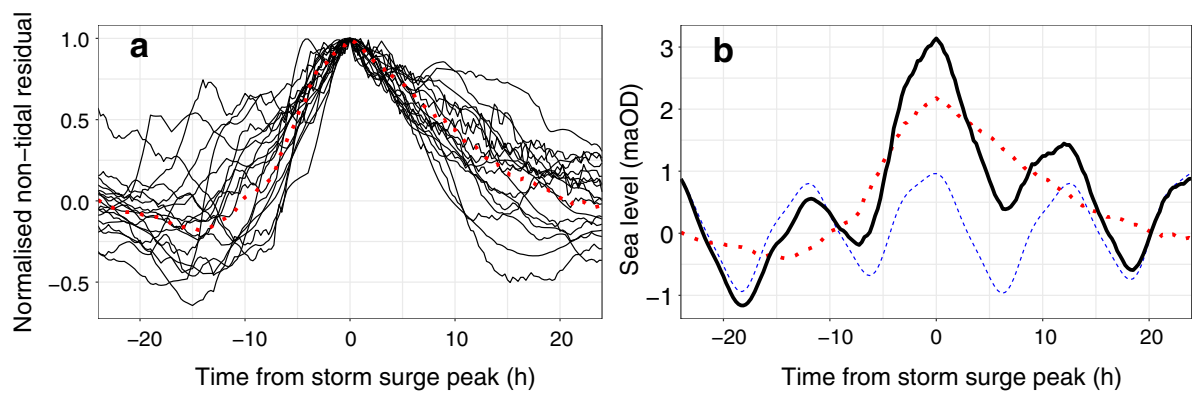

Fig. 6 a Average surge shape (red, dotted) estimated from the 20 largest surges at Lowestoft between 1964 and 2015. b Synthetic total sea level (black) derived from the surge residual (red, dotted) and the combination of a base astronomical tide) and the 2015 mean sea level (blue, dashed)

storm surge shape is similar to the rest of the sample (Fig. 6a) and can be considered representative of historical events. Moreover, by choosing the non-tidal residuals and not total sea level peaks to determine an average storm surge shape, large storm surges that may have occurred during low tide are also taken into account. An extreme sea level event stage hydrograph for a target maximum level can thereby be recreated using this average surge shape, a base tidal prediction and MSL (Fig. 6b).

The skew surge is the difference between the predicted astronomical high tide and the nearest experienced high water. Since meteorological processes are independent of tidal forces, a surge can occur at any stage of the tide. Other studies have performed a joint probability analysis to form a probability distribution of total sea levels from the distribution of skew surges and peak tide levels (McMillan et al. 2011). The assumption was made here that the storm surge peak coincided with the mean high predicted tide. This method, also used by Webster et al. (2014), was justified by analysing past extreme storm surge events that led to flooding concerns in the study area, which tended to occur at or near high tide.

An analogous method was applied to create synthetic flow hydrographs. The hydrograph shape of the last 20 most important storms in terms of flow at Horstead Mill on the River Bure was analysed to produce an average event shape. Due to limited data availability, upstream boundaries at the River Yare and internal boundaries at the tributaries of the River Bure were assumed to be proportional to the discharge rate at Horstead Mill based on their relative drainage areas. This is a common method used for ungauged catchments (Webster et al. 2014) that assumes similar hydrogeological characteristics. Drainage areas were determined in ArcGIS using $30 \mathrm{~m}$ by $30 \mathrm{~m}$ resolution Shuttle Radar Topography Mission (SRTM) data (Table 1). Initial conditions for both stage and discharge are taken directly from the boundary data.

\section{Results and discussion}

\subsection{EVA and scenario definition}

Exploratory semi-structured interviews were conducted with a set of 11 stakeholders to identify priorities, interests and to help base the definition of scenarios on local knowledge. Stakeholders were chosen from professionals with extended knowledge of the Broads, and 
Table 1 Drainage area of upstream and internal boundaries for the HEC-RAS model used to estimate flow hydrographs relative to the River Bure

\begin{tabular}{lc}
\hline River & Drainage area at model boundary $\left(\mathrm{km}^{2}\right)$ \\
\hline Bure & 336.54 \\
Ant & 145.24 \\
Thurne & 119.35 \\
Spix & 59.94 \\
Yare & 1392.57 \\
Waveney & 891.43 \\
\hline
\end{tabular}

active residents with a long-lasting interest in the area's overall management. Specific experience in flood management varied greatly as participants covered a wide range of sectors such as farming, angling, environmental protection, engineering and coastal management. The interviews confirmed the importance of tidal and coastal sources of flooding in the Broads and highlighted vulnerable locations such as-but not limited toGreat Yarmouth or several protected areas. One of the main recurring statements emphasised in the interviews was a concern for the risk of combined events. More specifically, the occurrence of a storm surge during high river discharge was identified as a worry for different stakeholders. Although the small sample of participants does not allow for statistically significant conclusions, this information was used to guide modelling choices and define future scenarios.

A comparison of the available data on past peak sea levels, non-tidal residuals and discharge shows that these events do not tend to occur simultaneously (Fig. 7). However, Fig. 7 also shows that it is physically possible for the peak of the storm surge to occur during a high discharge event and therefore near peak flow.

The EVA served to find return levels of both extreme sea level and extreme discharge to define representative downstream and upstream boundary conditions, respectively. The purpose of the EVA was not to provide a robust probabilistic assessment of flooding risk from different or combining sources. Without an analysis of the probability of joint occurrence of high tide and extreme storm surge, it was not possible to assign return levels to entire extreme sea level events. The EVA performed on total sea levels however did provide return levels for the peak of recreated extreme events.

The GP distribution performed relatively well to describe both extreme sea level (Fig. 8a) and extreme discharge (Fig. 8b). It should be noted that the most extreme values were found above the fitted distribution curves. These events corresponded to the December 2013 storm surge and a peak river flow in April 1981. Both occurrences were

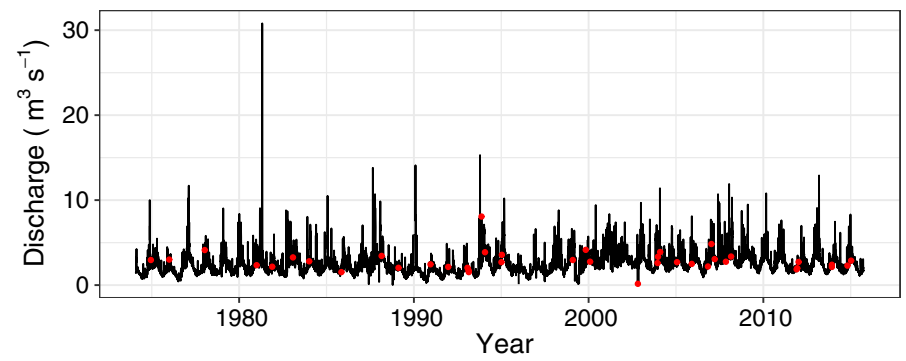

Fig. 7 The timing of the 40 highest non-tidal residuals (red points) decomposed from sea level data at Lowestoft, UK compared to river discharge at Horstead Mill between 1974 and 2015 

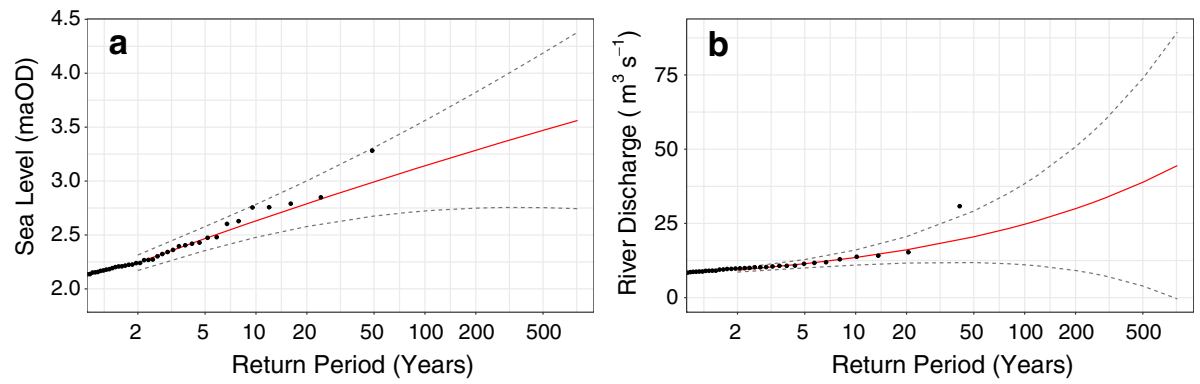

Fig. 8 Return levels at the reference year 2015 for a sea level at Lowestoft, UK expressed in relation to ordnance datum and b river discharge at Horstead Mill. The dashed lines represent the $95 \%$ confidence intervals

verified using data from other nearby gauges, and it was therefore decided not to discard them as recording errors. These points were by far the most extreme observations and did not provide strong evidence against the choice of the GP distribution function compared to other tested distribution functions. The lack of data is a common issue in EVA. More investigation using other sources of data (such as news reports if they exist) that extend past the recorded data period would allow for more confidence in this estimation.

Evidence suggests that changes in MSL are the primary factor leading to an increase in extremes sea levels (Menéndez and Woodworth 2010). Relative MSL (RMSL) is not only rising, but has also been found to accelerate at various rates around the world, with a trend of $4.4 \pm 1.1 \mathrm{~mm} \mathrm{a}^{-1}$ estimated at Lowestoft from 1993 to 2011 by Wahl et al. (2013). It indeed remains highly uncertain how climate change will impact local storm surge patterns. A linear increase in RMSL was assumed to determine future conditions and return levels up to the year 2100. Uncertainty moreover resides in current projections of the rate of SLR in the twenty-first century. Pfeffer et al. (2008) found that accelerated sea-level rise between $0.8 \mathrm{~m}$ and $2 \mathrm{~m}$ up to 2100 was physically plausible depending on glaciological conditions. To account for such possibilities, extreme scenarios of $1 \mathrm{~m}$ and $2 \mathrm{~m}$ MSL rise by 2100 were also considered.

While seasonal precipitation changes are expected in the UK, notably with an increased proportion of heavy precipitation events occurring during winter months, current projections do not show significant changes in annual precipitation in East Anglia (Jenkins 2009). Moreover, little is known on the intensity of extreme precipitation events in coming decades and therefore which trajectory river discharge will also follow. Patterns of extreme river discharge were therefore assumed to the same up to 2100 as in 2015 in the presented scenarios. This assumption is moreover warranted by the much greater influence of tidal processes in the Broads.

The chosen scenarios are presented in Table 2. They included three scenarios of 100-year return peak sea levels under different MSL rise pathways. As explained in Sect. 3.2.2, only the peak sea level is assigned a 100-year return period as opposed to the entire event. Each storm surge event was then also combined with a simultaneous 100-year return river discharge to test the sensitivity of the study area to coinciding extreme events. The timing of events can have significant impacts on flooding occurrence and extent. It is therefore important to note that previous studies have found it most likely for these types of events to not coincide with up to several days separating the different extremes (Klerk et al. 2015). With these caveats taken into account, the proposed scenarios provide a basis to assess the sensitivity of the Broads to compound flooding. 
Table 2 Scenario names

\begin{tabular}{llll}
\hline $\begin{array}{l}\text { Upstream boundary- } \\
\text { river flow }\end{array}$ & Downstream boundary-sea level & \\
\cline { 2 - 4 } & $\begin{array}{l}2100-4 \mathrm{~mm} \mathrm{a}^{-1} \text { MSL rise } \\
1: 100 \text { peak sea level event }\end{array}$ & $\begin{array}{c}1 \mathrm{~m} \mathrm{MSL} \text { rise } \\
1: 100 \text { peak sea } \\
\text { level event }\end{array}$ & $\begin{array}{c}2 \mathrm{~m} \text { MSL rise } \\
1: 100 \text { peak sea } \\
\text { level event }\end{array}$ \\
\hline Base & $2100 \mathrm{Q} 0$ & $1 \mathrm{mQ0}$ & $2 \mathrm{mQ0}$ \\
$1: 100$ event & $2100 \mathrm{Q} 100$ & $1 \mathrm{mQ} 100$ & $2 \mathrm{mQ} 100$ \\
\hline
\end{tabular}

\subsection{Calibration and validation}

The HEC-RAS model was calibrated and validated with storm surge events from October 2014 and December 2013, respectively. The calibration parameter used was the Manning's $n$ roughness coefficient. Data on past flooding inundation extent in the Broads are lacking in both availability and accuracy. While there have not been major flooding events since 1953, localised defence failures have been observed during extreme storm surge events. Spencer et al. (2015) provided an account of the impact of the December 2013 storm surge along the Norfolk coast. Tidal flooding was however also observed further inland due to overtopping and reported in parts of the Broads (Broads Authority, 2014). As there is no record of the spatial footprint of this inundation, the validation process was carried out using river levels at different stations on the Bure and the Yare (Fig. 6), as well as reports from the Broads Authority, news articles, dated photos, and local accounts of flooding.

Descriptions of the local environments and recommended ranges obtained from Chow (1959) served to make initial benchmarks for Manning's $n$ values. The model's calibration was performed on the Manning's $n$ within river channels to reach final values as shown in Table 3. A roughness coefficient was also applied to land classes out of the river banks in the $2 \mathrm{D}$ modelling domain. These values were not used during the model's calibration as

Table 3 Manning's $n$ in river channels after calibration

Table 4 Manning's $n$ for different land classes

\begin{tabular}{ll}
\hline Land cover & Manning's $n$ roughness coefficient \\
\hline River Bure & 0.045 \\
River Ant & 0.045 \\
River Thurne & 0.045 \\
River Yare-Great Yarmouth & 0.04 \\
River Yare-Breydon Water & 0.025 \\
River Yare-Upper & 0.03 \\
River Waveney & 0.04 \\
\hline
\end{tabular}

\begin{tabular}{ll}
\hline Land cover & Manning's $n$ roughness coefficient \\
\hline Arable and horticulture & 0.05 \\
Broadleaf woodland & 0.15 \\
Fen, marsh and swamp & 0.07 \\
Improved grassland & 0.035 \\
Urban areas & 0.2
\end{tabular}





Fig. 9 Observed (black) and modelled (red dashed) river levels during the December 2013 storm surge at a Haven Bridge, b Three Mile House, c Burgh Castle, d Acle, and e Hoveton Broad

flood extent data were not available (Table 4). In tidally influenced rivers, the inertial terms in the momentum equation are important and rivers levels are not highly sensitive to adjustments in the roughness coefficient (USACE 2016). Theta is a weighting factor that ranges between 0.6 (more accurate) and 1.0 (more computationally stable) applied to the finite difference approximations when solving the unsteady flow equations. A Theta value of 0.6 was used to improve the accuracy in the representation of the propagating tidal wave, which did not decrease the model's stability.

As expected, the model performed well at recreating river levels near the model's downstream boundary condition in Great Yarmouth at Haven Bridge (Fig. 9a) with an NSE of 0.92. The model also performed well upstream on both the River Bure and the River Yare, at the Three Mile House (Fig. 9b) and Burgh Castle (Fig. 9c) gauges, respectively. It should be noted that the instrument at Three Mile House was unable to measure the river level during the peak of the tide on 06/12/2013. The NSE remained relatively high at 0.84 . The gauge at Burgh Castle is a flood warning monitoring station only and due to the position of its pressure sensor instrument, it therefore does not measure any levels below 0 maOD. Still, the model produced a good fit to both the level of the peaks and their timing at Burgh Castle. The model's performance decreased upstream of the River Bure. At Acle, once the tidal wave had propagated, the NSE dropped to 0.67 and there was a slight shift in the timing of the tide (Fig. 9d). The modelled peak river level remained within $0.03 \mathrm{~m}$ of the observed value. Nearly $40 \mathrm{~km}$ from the sea, the error increased further upstream towards Hoveton Broad, where the model overestimated the 
river level by a maximum of $0.1 \mathrm{~m}$. While river levels were high during this event, the defences were largely successful in holding back the water from the floodplains. This was also the case in the model's recreation of the event, where only localised flooding was visible at moorings located near Berney Arms, which allowed water to flow into Halvergate Marshes.

\subsection{Hydrodynamic simulations}

Model results derived from simulations in HEC-RAS were exported to ArcGIS and R for analysis. The maximum flooding depth from each simulation run can be found in Fig. 10. The inundation extent shown in these profiles represents an aggregation of the overall runs rather than a specific simulation time. The profiles should therefore be differentiated with the extents occurring during maximum sea level, since flooding is dynamic and its timing


Fig. 10 Maximum flooding depth in the Broads between Great Yarmouth and Horstead Mill on the River Bure under different extreme scenarios (simulation names from Table 3). a 2100Q0, b 2100Q100, c 1mQ0, d $1 \mathrm{mQ} 100$, e $2 \mathrm{mQ} 0, \mathbf{f} 2 \mathrm{mQ} 100$ 
varies across various locations. Extreme sea levels cause flooding both downstream and upstream in the Broads when assuming a linear mean SLR up to 2100 (Fig. 10a). The largest affected area is Halvergate Marshes, where water is able to flow throughout the large floodplain located north of Breydon Water. Elevated roads and railway tracks are well captured by the model's 2D mesh and slow the propagation of the flood wave. Flooding is minimal in the more densely populated Great Yarmouth as there is almost no overtopping of high defences. With the exception of Halvergate Marshes, flood walls and levees are successful in preventing extensive flooding. Upstream of Ranworth Broads, the floodplains are unprotected and consist mostly of marshes that are well connected to the river. While buildings near the riverbanks in the towns of Horning and Hoveton are affected, the flood depth remains relatively low. As Fig. 10b shows, combining this event with a 1:100 return river discharge has significant consequences on flooding on the upstream boundary of the tidal Bure. Impacts downstream remain limited. As SLR has been observed to accelerate in the last decades, a linear increase in RMSL over the next century is a conservative assumption. Scenarios representing an accelerated rise leading up to $1 \mathrm{~m}$ and $2 \mathrm{~m}$ increase in MSL are shown in Fig. 10c-f.

The topology of the rivers and floodplains in the Broads causes flooding to occur rapidly and spread significantly when a defence is overtopped. Figure 10 shows that certain areas are susceptible to lower thresholds of embankment failure, thereby flooding first and highlighting potential vulnerabilities. A notable observation from the scenarios with a $1 \mathrm{~m}$ and $2 \mathrm{~m}$ RMSL rise is the increased impact on Great Yarmouth. Not only are more tidal defences overtopped, but coastal waters are also able to flow into the town directly from the sea and cause more flooding at some simulation time steps. These interacting sources of flooding lead to an important increase in impacted buildings (Table 5). While a $2 \mathrm{~m}$ increase in MSL by 2100 is still considered unlikely and would require a drastic acceleration of SLR, this scenario is useful to highlight the area's sensitivity. For example, the model showed flooding outside of some of the left banks of the Bure only during scenarios $2 \mathrm{mQ0}$ and 2mQ100. The main urban zone in the study area is Great Yarmouth, located near the coast. Sea level is therefore the main driver for the number of flooded buildings. Other towns located farther upstream in the Broads are also affected. Centres of activity for tourism and sailing in Horning and Hoveton lie in close proximity to the River Bure, and several buildings in both towns are susceptible to flooding in all scenarios.

While flooding occurs in all the presented scenarios, both extent and depth vary greatly between the different simulations. Depth is important to consider for risk management as it is used in determining flood damage. Figure 11 shows the density of flooded 2-m cells by depth in all six scenarios. Although the flooding extent was already high in scenario 2100Q0, most of the flooding occurred at low depths between $0 \mathrm{~m}$ and $0.5 \mathrm{~m}$, meaning actual damages would be limited or easier to cope with (Fig. 11a). The maximum density

Table 5 Number of buildings affected by flooding under different extreme scenarios in the model study area

\begin{tabular}{lcc}
\hline Scenario & Number of buildings flooded & Proportion of buildings flooded (\%) \\
\hline $2100 \mathrm{Q} 0$ & 702 & 16.78 \\
$2100 \mathrm{Q} 100$ & 892 & 21.32 \\
$1 \mathrm{mQ0}$ & 1285 & 30.72 \\
$1 \mathrm{mQ100}$ & 1389 & 33.21 \\
$2 \mathrm{mQ0}$ & 1635 & 39.09 \\
$2 \mathrm{mQ100}$ & 1797 & 42.96 \\
\hline
\end{tabular}





Fig. 11 Kernel density plots of flooded cells by depth for scenarios a 2100Q0 (blue), 2100Q100 (red, dotted line), b 1mQ0 (blue), 1mQ100 (red, dotted line) and c 2mQ0 (blue), 2mQ100 (red, dotted line)

shifts towards $0.5 \mathrm{~m}$ and $1 \mathrm{~m}$ for scenario $1 \mathrm{mQ0}$ (Fig. 11b) and increases considerably to over $2 \mathrm{~m}$ for scenario 2mQ0 (Fig. 11c).

Both Table 5 and Fig. 11 emphasise that increasing RMSL has a significant impact on inundation extent and depth in the Broads. While sea level is indeed the main driver for flooding in the study area, the results also show that coinciding high river flows can exacerbate these impacts. The average depth of cells below $5 \mathrm{~m}$ in depth increased from $0.82 \mathrm{~m}$ to $1.08 \mathrm{~m}$ (Fig. 11a), from $0.92 \mathrm{~m}$ to $1.16 \mathrm{~m}$ (Fig. $11 \mathrm{~b}$ ) and from $1.9 \mathrm{~m}$ to $2.09 \mathrm{~m}$ (Fig. 11c) for the three scenario pairs, respectively. A similar pattern can be observed for the total area of the flooding in each scenario. For both average depth and inundation area however, the influence of high discharge decreases as the maximum sea level increases. Average flood depth increases by $40 \%$ from scenarios $2100 \mathrm{Q} 0$ to $2100 \mathrm{Q} 100$, while it increases by $5 \%$ from scenarios $2 \mathrm{mQ} 0$ to $2 \mathrm{mQ} 100$. Similarly total inundated area increases 

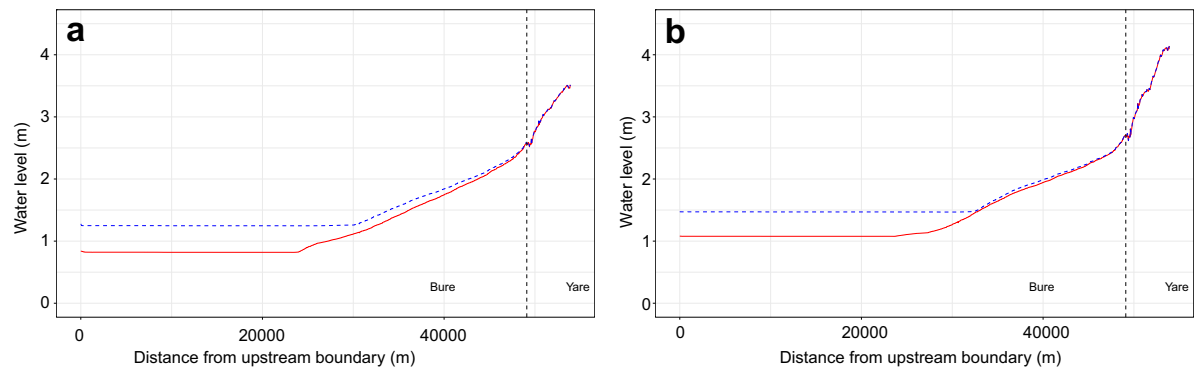

Fig. 12 Longitudinal profile view of maximum water levels along the River Bure and River Yare from the model's upstream boundary to its downstream boundary, the North Sea. a Maximum water levels for scenarios 2100Q0 (red) and 2100Q100 (blue, dashed). b Maximum water levels for scenarios 1mQ0 (red) and 1mQ100 (blue, dashed)

by $32 \%$ from scenarios $2100 \mathrm{Q} 0$ to $2100 \mathrm{Q} 100$ compared to a $10 \%$ rise from scenarios $2 \mathrm{mQ0}$ to $2 \mathrm{mQ} 100$.

The simulated compound events did not have significant added consequences in Great Yarmouth on either flooding extent or depth, compared to unique events of extreme sea level. The longitudinal profile of the modelled rivers indeed shows that the influence of the combined extreme discharge decreases going downstream (Fig. 12). Near the mouth of the River Yare, the extreme discharge has almost no impact on the water level in all three envisaged cases. Figure 12 also shows that the difference in water level between Q0 and Q100 events is greater for a lower MSL. Upstream areas are much more affected. The flooded area of broadleaf woodland, which occurs mostly upstream of Ranworth Broads along the River Bure, is highly influenced by the occurrence of a combined event (Fig. 12, Table 6). The Bure Broads and Marshes are well connected to the river, and the encroachment of water is therefore not a direct concern or a rare occurrence.

The deeper upstream flooding observed in Fig. 10b, c and d remains significant as it can lead to longer residence times of saline waters. Large areas of improved grassland, notably used for grazing, are predisposed to flooding under each scenario, with arable and horticulture land classes also highly impacted (Table 6). There are moreover several protected areas, such as sites of specific interests (SSSI), located in the Broads. A topic for future research would be the impact of extreme events on salinity in the Broads. Salinity can cause damage to agricultural land and therefore lead to significant economic losses as well as representing a threat to sensitive species. Studying the impact of combined events may lead to counter-intuitive results as several processes affect salinity. Indeed, high river flows

Table 6 Area flooded by land-cover class $\left(\mathrm{km}^{2}\right)$

\begin{tabular}{lcclccc}
\hline Scenario & $\begin{array}{l}\text { Broadleaf } \\
\text { woodland }\end{array}$ & $\begin{array}{l}\text { Arable and } \\
\text { horticulture }\end{array}$ & $\begin{array}{l}\text { Improved } \\
\text { grassland }\end{array}$ & $\begin{array}{l}\text { Fen, marsh and } \\
\text { swamp }\end{array}$ & Urban & $\begin{array}{l}\text { Sub- } \\
\text { urban }\end{array}$ \\
\hline 2100Q0 & 6.31 & 1.01 & 23.27 & 6.92 & 1.45 & 0.16 \\
2100Q100 & 8.91 & 2.16 & 33.14 & 8.65 & 1.60 & 0.31 \\
1mQ0 & 7.93 & 3.34 & 35.86 & 8.08 & 4.59 & 0.56 \\
1mQ100 & 10.41 & 6.73 & 47.89 & 9.14 & 4.69 & 0.74 \\
2mQ0 & 12.83 & 14.22 & 61.52 & 10.02 & 6.73 & 1.58 \\
2mQ100 & 14.22 & 15.92 & 63.26 & 10.09 & 6.77 & 1.86 \\
\hline
\end{tabular}


add freshwater to the system, while surges push saline water upstream into the Broads. River salinity and conductivity can be simulated in HEC-RAS's water quality module.

A significant benefit of the described 1D-2D approach in portraying overtopping is the use of specific lateral structures for flood defences to guarantee that maximum crest heights were accounted for, regardless of the chosen mesh resolution. It is a fundamental requirement for 2D cells in HEC-RAS to be set up such that cell edges (or "faces") align with high ground or structures impeding the movement of water. This task can be difficult for narrow flood defences, even with a relatively fine resolution of $2 \mathrm{~m}$. Cells that are too large or that are not adequately oriented can cause issues with the model's calculations, leading water to incorrectly "leak" through natural or man-made barriers. The results in such cases are fragmented and therefore produce unrealistic outputs of flooding extents. The Broads is a highly engineered area with many embankments protecting large expanses of land from rivers. It was therefore essential to use lateral structures between 1D and 2D domains that capture the height of defences for their entire lengths. Until computational capabilities increase to allow for extremely fine mesh resolutions, this study finds that a 1D-2D method remains the most feasible approach for the geographical location in question.

The HEC-RAS 1D-2D model was able to highlight vulnerabilities and weak points within the study area as well as account for complex interactions between different sources of flooding. The model structure could still be improved by including building footprints in the 2D mesh to better represent the flow of water in urban areas. Such levels of accuracy were however not necessary to assess the overall sensitivity of the case study area and the fitness for use of the HEC-RAS model version 5.0. Further developments for the model could moreover be to include other parts of the Broads that currently lie outside the modelling domain. Areas in the River Yare, Waveney, Thurne and Ant basins, as well as in Lowestoft have experienced flooding in the past.

Several important considerations should be made when interpreting the results derived from the presented hydraulic model. The first is that while flood defence infrastructure can fail in a number of ways, only the overtopping of defences was considered here. The erosion and breaching of dunes, embankments and walls are a common concern in coastal regions (Hall et al. 2015). Although these processes can be simulated in HEC-RAS and can be useful to represent catastrophic or "what if" scenarios, their impacts fell outside of the scope of this study.

A more comprehensive study of flooding risk would moreover need to incorporate processes of wind and waves, which were omitted in this simplified hydraulic modelling framework. Wind is a key parameter that plays a role in the dynamics of both waves and surges and can therefore have important consequences on coastal flooding. With the necessary data, the EVA and the scenarios used for simulations could therefore be refined by setting up local wave and storm surge models (e.g. Villatoro et al. 2014). Similarly, the lack of available discharge data was also a limitation for this work. A hydrological model could be used in future research to determine more accurate upstream boundaries for the HEC-RAS hydraulic model. A hydrological model would moreover make it possible to account for projected changes in temperature and precipitation in the Broadland catchment to better understand the impact of these climatic changes on flooding hazard.

This study highlighted the potential for multiple extreme events occurring simultaneously to exacerbate flooding risk in the Broads. Validating the proposed modelling framework to assess the sensitivity of the Broads, the aim of this research was however not to understand the probabilities of co-occurrence of these events. The assumption was made that peak river discharge and peak sea level occurred simultaneously in scenarios where 
both events occurred. While it helped in interpreting the created scenarios, this assumption may not be representative of likely events in the Broads. Past studies in other regions, such as the Netherlands, have, for example, shown a dependency between discharge peaks and water levels, but with a lag time of several days (Klerk et al. 2015). More analysis should be performed to determine the dependency between discharge peaks and sea levels in the East coast of England. Moreover, understanding the types of weather patterns associated with different events could provide some useful insights into flooding hazard in the region. As the timing of events can have significant consequences not only of flooding extent but also on the usefulness of flood mitigation strategies, joint probabilities should be carefully considered to make robust planning recommendations on flood risk management.

\section{Conclusions}

This study has looked to evaluate the sensitivity of a complex coastal environment to different sources of flooding, using the new tools made available in HEC-RAS version 5.0. A 1D-2D approach was found to be appropriate for flood mapping in this context, accurately reproducing the flow of water in both large floodplains and urban areas while reducing computational requirements. Lower simulation run times moreover made it possible to cover a larger area from the coast and to $40 \mathrm{~km}$ inland where tidal and fluvial processes interact. The proposed approach is particularly relevant to low-lying and lowgradient regions like the Broads, which are prone to tidal flooding and where the tidal boundary extends far upstream. There will continue to be more opportunities for 2D modelling in the UK as the coverage of fine-resolution LIDAR data grows.

Hydraulic models are not only sensitive to topographical data but also to the choice and fundamental design of boundary conditions. With extremes being the primary cause of flooding in the Broads and in many regions around the world, it is important to capture the hydrological conditions occurring during these events. The GPD function was used to determine return levels of sea level and river discharge to create synthetic extreme events under future conditions of SLR. Important assumptions were made to create simplified synthetic events as the interest of this work was to assess the sensitivity of the Broads to extreme flooding and the potential for the modelling framework to map out maximum flooding extents. Peak river discharge and sea level were thereby designed to occur at the same time. Similarly, the storm surge peak coincided with the highest point in the tide cycle. For a more comprehensive assessment of flood risk, further research should look into the significance of the timing of these events as well as the joint probability of their occurrence. The proposed model however helps to understand the Broads' sensitivity to different sources of flooding. Storm surges are, and are likely to continue to be, the main drivers for flooding in the Broads as RMSL rises over the next century. While there is still uncertainty in the pattern of future precipitation with climate change, this study has shown that high discharge could exacerbate the flooding caused by storm surges.

While the described hydraulic model can be expanded to cover a larger portion of the Broads, this case study highlights the potential for 1D-2D modelling in assisting decisionmaking. This methodology indeed allows for the consideration of urban coastal areas, requiring a high amount of detail, as well as vast inland rural zones. It is moreover suited to dynamically represent interacting sources of flooding and potential combined extreme events. The presented approach is therefore a step towards helping meet the requirements of integrated catchment management as well as flood alleviation and adaptation. 
Acknowledgements The first author is supported by the Natural Environment Research Council as part of a CASE partnership with the Broads Authority. The authors would like to thank the editors of the Special Issue in "Advances in extreme value analysis and Application to Natural Hazards", Dr Ivan Haigh and Dr Thomas Wahl, for their valuable comments and for the organisation of the 2017 EVAN Conference.

Open Access This article is distributed under the terms of the Creative Commons Attribution 4.0 International License (http://creativecommons.org/licenses/by/4.0/), which permits unrestricted use, distribution, and reproduction in any medium, provided you give appropriate credit to the original author(s) and the source, provide a link to the Creative Commons license, and indicate if changes were made.

Funding The Corresponding Author (Ulysse Pasquier) received a $\mathrm{PhD}$ studentship from the Natural Environment Research Council as part of a CASE partnership with the Broads Authority. Award Number: NE/L002582/1

\section{References}

Arns A, Wahl T, Haigh ID, Jensen J, Pattiaratchi C (2013) Estimating extreme water level probabilities: a comparison of the direct methods and recommendations for best practise. Coast Eng 81:51-66

Barredo JI (2009) Normalised flood losses in Europe: 1970-2006. Nat Hazard Earth Syst Sci 9(1):97-104

Bezak N, Brilly M, Šraj M (2014) Comparison between the peaks-over-threshold method and the annual maximum method for flood frequency analysis. Hydrol Sci J 59(5):959-977. https://doi.org/10.1080/ 02626667.2013 .831174

Broads Authority (2014) Reflections on the December Tidal Surge and how this relates to adapting to environmental changes in the Broads. http://www.broads-authority.gov.uk/_data/assets/pdf_file/0006/ 426597/Reflections-on-the-December-Tidal-Surge-and-How-This-Relates-to-Adaption-toEnvironmental-Change-in-the-Broads.pdf. Accessed 28 Sept 2017

Chen L, Sign VP (2017) Generalized beta distribution of the second kind for flood frequency analysis. Entropy 19(6):254. https://doi.org/10.3390/e19060254

Chow VT (1959) Open-channel hydraulics. McGraw-Hill, New York

Church JA, Clarks PU, Cazenave A, Greogry JM, Jevrejeva S, Levermann A, Merrifield MA, Milne GA, Nerem RS, Nunn PD, Payne AJ, Pfeffer WT, Stammer D, Unnikrishnan AS (2013) Sea level change. In: Stocker TF, Qin D, Plattner GK, Tignor M, Allen SK, Boschung J, Nauels A, Xia Y, Bex V, Midgley PM (eds) Climate change 2013: the physical science basis. contribution of working group I to the fifth assessment report of the intergovernmental panel on climate change. Cambridge University Press, Cambridge and New York, pp 1137-1216

Environment Agency (2009) Broadland rivers catchment flood management plan: summary report December 2009. Environment Agency. http://www.broads-authority.gov.uk/news-and-publications/ publications-and-reports/conservation-publications-and-reports/water-conservation-reports/36.-BroadlandFlood-Management-Plan-2009.pdf. Accessed 28 Sept 2017

Haigh ID, Wadey MP, Wahl T, Ozsoy O, Nicholls RJ, Brown JM, Horsburgh K, Gouldby B (2016) Spatial and temporal analysis of extreme sea level and storm surge events around the coastline of the UK. Sci Data 3:160107

Hall JW, Dawson RJ, Wu XZ (2015) Analysing flood and erosion risks and coastal management strategies on the Norfolk coast. In: Nicholls RJ, Dawson RJ, Day SA (eds) Broad scale coastal simulation: new techniques to understand and manage shorelines in the third millennium, 1st edn. Springer, Dordrecht, pp 233-254

He Y, Pappenberger F, Manful D, Cloke HL, Bates P, Wetterhall F, Parkes B (2013) Flood inundation dynamics and socioeconomic vulnerability under environmental change. In: Hossain F (ed) Vulnerability of water resources to climate. Climate vulnerability, vol 5. Elsevier Sciences, pp 241-255. https://doi.org/10.1016/B978-0-12-384703-4.00508-6

Javaheri A, Babbar-Sebens M (2014) On comparison of peak flow reductions, flood inundation maps, and velocity maps in evaluating effects of restored wetlands on channel flooding. Ecol Eng 75:132-145

Jenkins G (2009) Exeter: met office hadley centre. UKCP09 Briefing report, UK Climate projections. http:// ukclimateprojections.metoffice.gov.uk/media.jsp?mediaid=87868\&filetype=pdf. Accessed 28 Sept 2017 
Kew SF, Selten FM, Lenderink G, Hazelger W (2013) The simultaneous occurrence of surge and discharge extremes for the Rhine delta. Nat Hazards Earth Syst Sci 13:2017-2029. https://doi.org/10.5194/nhess13-2017-2013

Klerk WJ, Winsemius HC, van Verseveld WJ, Bakker AMR, Diermanse FLM (2015) The co-incidence of storm surges and extreme discharges within the Rhine-Meuse Delta. Environ Res Lett 10:035005. https://doi.org/10.1088/1748-9326/10/3/035005

Mantz PA, Wakeling HL (1979) Forecasting flood levels for joint events of rainfall and tidal surge flooding using extreme value statistics. Proc Inst Civ Eng 67:31-50

McMillan A, Batstone C, Worth D, Tawn J, Horsburgh K, Lawless M (2011) Coastal flood boundary conditions for UK mainland and islands. Environmental Agency, Bristol

Menéndez M, Woodworth PL (2010) Changes in extreme high water levels based on a quasi-global tidegauge data set. J Geophys Res Oceans 115:C10011. https://doi.org/10.1029/2009JC005997

Néelz S, Pender G (2009) Desktop review of 2D hydraulic modelling packages. DEFRA/Environment Agency. http://evidence.environment-agency.gov.uk/FCERM/Libraries/FCERM_Project_Documents/ SC080035_Desktop_review_of_2D_hydraulic_packages_Phase_1_Report.sflb.ashx. Accessed 28 Sept 2017

Patel DP, Ramirez JA, Srivastava PK, Bray M, Dawai H (2017) Assessment of flood inundation mapping of Surat city by coupled 1D/2D hydrodynamic modeling: a case application of the new HEC-RAS 5. Nat Hazards 89(1):93-130

Pfeffer WT, Harper JT, O’Neel S (2008) Kinematic constraints on glacier contributions to 21st-century sealevel rise. Science 321(5894):1340-1343

Pugh DJ (1996) Tides, surges and mean sea level. A handbook for engineers and scientists. Wiley, Chichester

Quiroga VM, Kure S, Udo K, Mano A (2016) Application of 2D numerical simulation for the analysis of the February 2014 Bolivian Amazonia flood: application of the new HEC-RAS version 5. RIBAGUARevista Iberoamericana del Agua 3:25-33

Ray T, Stepinski E, Sebastian A, Bedient PB (2011) Dynamic modeling of storm surge and inland flooding in a Texas coastal floodplain. J Hydraul Eng 137(10):1103-1111

Rouillard JJ, Ball T, Heal KV, Reeves AD (2015) Policy implementation of catchment-scale flood risk management: learning from Scotland and England. Environ Sci Policy 50:155-165

Saeed Far SS, Abd. Wahab AK (2016) Evaluation of peaks-over-threshold method. Ocean Sci Discuss. https://doi.org/10.5194/os-2016-47

Shrestha S, Lohpaisankrit W (2016) Flood hazard assessment under climate change scenarios in the Yang River Basin, Thailand. Int J Sustain Built Environ. https://doi.org/10.1016/j.ijsbe.2016.09.006

Spencer T, Brooks SM, Evans BR, Tempest JA, Moller I (2015) Southern North Sea storm surge event of 5 December 2013: water levels, waves and coastal impacts. Earth Sci Rev 145:120-145. https://doi.org/ 10.1016/j.earscirev.2015.04.002

Stevens AJ, Clarke D, Nicholls RJ (2016) Trends in reported flooding in the UK: 1884-2013. Hydrol Sci 61:50-63. https://doi.org/10.1080/02626667.2014.950581

Svensson C, Jones DA (2002) Dependence between extreme sea surge, river flow and precipitation in eastern Britain. Int J Climatol 22:1149-1168

Teng J, Jakeman AJ, Vaze J, Croke BFW, Dutta D, Kim S (2017) Flood inundation modelling: a review of methods, recent advances and uncertainty analysis. Environ Model Softw 90:201-216

USACE (2016) HEC-RAS river analysis system user's manual version 5.US Army Corps of Engineers. http://www.hec.usace.army.mil/software/hec-ras/documentation/HEC-RAS\%205.0\%20Users\% 20Manual.pdf Accessed 28 Sept 2017

van den Hurk B, van Meijgaard E, de Valk P, van Heeringen K-J, Gooijer J (2015) Analysis of a compounding surge and precipitation event in the Netherlands. Environ Res Lett 10:035001. https://doi. org/10.1088/1748-9326/10/3/035001

Villatoro M, Silva R, Mendez FJ, Zanuttigh B, Pan S, Trifonova E, Losada IJ, Izaguirre C, Simmonds D, Reeve DE, Mendoze E, Martinelli L, Formentin SM, Galiatsatou P, Eftimova P (2014) An approach to assess flooding and erosion risk for open beaches in a changing climate. Coast Eng 87:50-76. https:// doi.org/10.1016/j.coastaleng.2013.11.009

Vozinaki A-EK, Morianou GG, Alexakis DD, Tsanis IK (2017) Comparing 1D and combined 1D/2D hydraulic simulations using high-resolution topographic data: a case study of the Koilaris basin, Greece. Hydrol Sci J 62(4):642-656. https://doi.org/10.1080/02626667.2016.1255746

Wahl T, Haigh ID, Woodworth PL, Albrecht F, Dillingh D, Jensen J, Nicholls RJ, Weisse R, Wöppelmann G (2013) Observed mean sea level changes around the North Sea coastline from 1800 to present. Earth Sci Rev 124:51-67. https://doi.org/10.1016/j.earscirev.2013.05.003 
Wahl T, Jain S, Bender J, Meyers SD, Luther ME (2015) Increasing risk of compound flooding from storm surge and rainfall for major US cities. Nat Clim Change 5:1093-1097. https://doi.org/10.1038/ nclimate 2736

Wang G, Wang D, Trenberth KE, Erfanian A, Yu M, Bosilovich MG, Parr DT (2017) The peak structure and future changes of the relationships between extreme precipitation and temperature. Nat Clim Change 7:268-274. https://doi.org/10.1038/nclimate3239

Webster T, McGuigan K, Collins K, MacDonald C (2014) Integrated river and coastal hydrodynamic flood risk mapping of LaHavre River Estuary and Town of Bridgewater, Nova Scotia, Canada. Water 6:517-546. https://doi.org/10.3390/w6030517

Whitfield PH (2012) Floods in future climates: a review. J Flood Risk Manag 5:336-365. https://doi.org/10. 1111/j.1753-318X.2012.01150.x

Wilby RL, Beven KJ, Reynard NS (2008) Climate change and fluvial flood risk in the UK: more of the same? Hydrol Process 22:2511-2523. https://doi.org/10.1002/hyp.6847

Wong PP, Losada IJ, Gattuso JP, Hinkel J, Khattabi A, McInnes KL, Saito Y, Sallenger A (2014) Coastal systems and low-lying areas. In: Field CB, Barros VR, Dokken DJ, Mach KJ, Mastrandrea MD, Billir TE, Chatterjee M, Ebi KL, Estrada YO, Genova RC, Girma B, Kissel ES, Levy AN, MacCracken S, Mastrandrea PR, White LL (eds) Climate change 2014: impacts, adaptation, and vulnerability. Part A: global and sectoral aspects. contribution of working group II to the fifth assessment report of the intergovernmental panel on climate change. Cambridge University Press, Cambridge and New York, pp 361-409

Wu XZ, Hall JW, Liang Q, Dawson RJ (2015) Broadscale Coastal Inundation Modelling. In: Nicholls RJ, Dawson RJ, Day SA (eds) Broad scale coastal simulation: new techniques to understand and manage shorelines in the third millennium, 1st edn. Springer, Dordrecht, pp 213-232

Zheng F, Westra S, Loenard M, Sisson SA (2014) Modeling dependence between extreme rainfall and storm surge to estimate coastal flooding risk. Water Resour Res 50:2050-2071. https://doi.org/10.1002/ 2013WR014616

\section{Affiliations}

\section{Ulysse Pasquier $^{1}$ (D) $\cdot \mathrm{Yi} \mathrm{He}^{1} \cdot$ Simon Hooton $^{2} \cdot$ Marisa Goulden $^{3} \cdot$ Kevin M. Hiscock ${ }^{4}$}

Ulysse Pasquier

u.pasquier@uea.ac.uk

1 Tyndall Centre for Climate Change Research, School of Environmental Sciences, University of East Anglia, Norwich Research Park, Norwich NR4 7TJ, UK

2 Broads Authority, Yare House, 62-64 Thorpe Road, Norwich NR1 1RY, UK

3 School of International Development, University of East Anglia, Norwich Research Park, Norwich NR4 7TJ, UK

4 School of Environmental Sciences, University of East Anglia, Norwich Research Park, Norwich NR4 7TJ, UK 